\title{
Application of Biogas Production Technology from Various Feedstocks on Small-Medium-Micro Enterprises: A Case Study
}

\author{
Ari Diana Susanti ${ }^{1, a,}$, Cornelius Satria Yudha ${ }^{2}$, Leader Firstandika ${ }^{2}$, Paryanto ${ }^{1}$, Wusana \\ Agung Wibowo ${ }^{1}$ \\ 1 Department of Chemical Engineering, Universitas Sebelas Maret, J1. Ir. Sutami No. 36 A, Surakarta, \\ Central Java, 57126 \\ 2 Master Student of Chemical Engineering Department, Universitas Sebelas Maret, Jl. Ir. Sutami No. 36 A, \\ Surakarta, Central Java, 57126 \\ E-mail: a,*aridiana@staff.uns.ac.id (Corresponding author)
}

\begin{abstract}
Biogas production process is an alternative method to reduce dependency on non-renewable fossil-based energy consumption and also can reduce greenhouse gases production both domestically and industrially. The existing biogas technology is suitable to be adapted in small-micro-medium enterprises and domestics, specifically for those who raise cattle. The case study was performed by observation of biogas production with various wastes as feed, namely cow dung, quail manure, and wastewater of tofu production. The study conducted via direct interviews with stake holders and visitations to the instalations. Based on our observation, biogas production from cow dung exhibits the shortest retention time compared to the others, aside from the value of $\mathrm{C} / \mathrm{N}$ ratio of the biogas feedstocks. The presence of biogas production installations are significantly reducing the energy supplies among the users. Beside as biogas product, the instalations also produce solid and liquid fertilizers as by-products and have relatively high economic value. Socio - engineering problems based on the application of biodigester are also studied.
\end{abstract}

Keywords: Biodigester, biogas, cow dung, quail manure, waste water of tofu industry.

EQUILIBRIUM Volume 2 No.2 July 2018

Online at http://equilibrium.ft.uns.ac.id 


\section{Introduction}

Energy has a major role in human lives as all activities depend on energy. The need of energy is increasing exponentially due to not only the development of transportation and industrial technology, but also due to domestic conveniences. The arousal of energy dependency each year could not be avoided while the source of conventional energies such as fossil-fuels is rapidly decreasing. This could cause the energy crisis which adverse national economy. The use of fossil-fuels also promotes climate change due to the green house gases (GHG) emission produced during energy generation. Due to the fact above, human kind needs to shift direction in terms of using energy that come from renewable sources [1].

The main text starts at the top of the page and continues in one column format. Place an indentation for each paragraph starting from the second in all sections or subsections. There is no space between paragraphs within the text. Add an 11-point space at both before and after the text in each section or subsection.

Biogas is one of new and renewable energy sources that could substitute the current gaseous fuel such as Liquified Petroleum Gases (LPG) which often used in domestics and micro enterprises [2]. It is technically, socially and economically feasible to be applied in farms and villages. Methane as one of its main compound is produced by conversion of organic matters by microorganism in an anaerobic environment. Organic matters as the feedstock could be varied from agricultural wastes to municipal wastes. Other major advantages exhibited by biogas is listed as follow [3]: (1) less CO2 emission compared to LPG per energy unit, (2) side product enriched with microorganism and light organic-inorganic compound adapted as bio-fertilizer, (3) hinders the spreading of cattle diseases through cattle manures, and (4) produce less harmful wastes.

Since late of 19th century, production of biogas by anaerobic digestion process were studied extensively based from the feedstocks [4 - 6], pretreatment of the feedstocks [2, 7], its process [8 - 10], and purification [11], while real-world problems in biogas application in farms and households are rarely discussed. While the technology has been discovered long ago, there are still problems that needed to be handled and obstacles faced by communities which adapt the technology, especially in developing countries. This paper reviews the implementation of biogas technology from farmers and small business owner's point of view. We conducted an observation of biogas production installation which established in Jagoan Village, Boyolali Regency and Mojosongo, Surakarta Regency where each area utilizes quails-cow manures and tofu industry waste as feedstock of the digester respectively.

\section{Methodology}

This research is an qualitative research. Data collecting were performed by direct observations and interviews from local biogas practicians. The direct observations were performed on December 2017 till January 2018 while the observations took place in Izzah Farm (Sambi, Boyolali) and Tofu Industry Centre, (Mojosongo, Solo). There are three interviewees or practicians : a laborant of veterinary department, Faculty of Agriculture, Universitas Sebelas Maret, a civil officers of Surakarta's environmental services agencies, and a Tofu homeindustry owner.

\section{Results and Discussions}

Based on the interviews, each case has significant difference in terms of biogas feedstock while there is no major differences in biogas installations. Biogas installations in village farm of Jagoan uses cow dung and quail's manure as the feedstock. Whereas the biogas plant established in tofu industry uses waste water of tofu production as the feedstock. Based on previous reviews the $\mathrm{C} / \mathrm{N}$ value of the feedstocks is listed in Table 1, the highest carbon to nitrogen ratio $(\mathrm{C} / \mathrm{N})$ is exhibited in tofu waste water. The high $\mathrm{C}$ level of tofu waste water mainly caused by the high starch content of the waste water while the $\mathrm{N}$ compound stays in the main product, tofu, in the form of protein. Quail's manure has the lowest $\mathrm{C} / \mathrm{N}$ ratio among two others which indicates high level of nitrogen due to its feed.

Table 1. Feedstock specification of biodigester

\begin{tabular}{lccc}
\hline Parameter & Cow Dung & Quail's manure & Tofu Industry Waste Water \\
\hline sector & Farm & Farm & Tofu industry \\
C/N Ratio & $\pm 25^{*}$ & $\pm 10,6^{* *}$ & $>30^{*}$ \\
\hline
\end{tabular}




\subsection{Process Production of Biogas}

Biogas production occurs inside a digester under anaerobic environments. Each studied subject of biogas installation uses the same design and concept of process. The digesters were constructed under the ground and dome-shaped. The flow chart of biogas productions are presented in Figure 1.
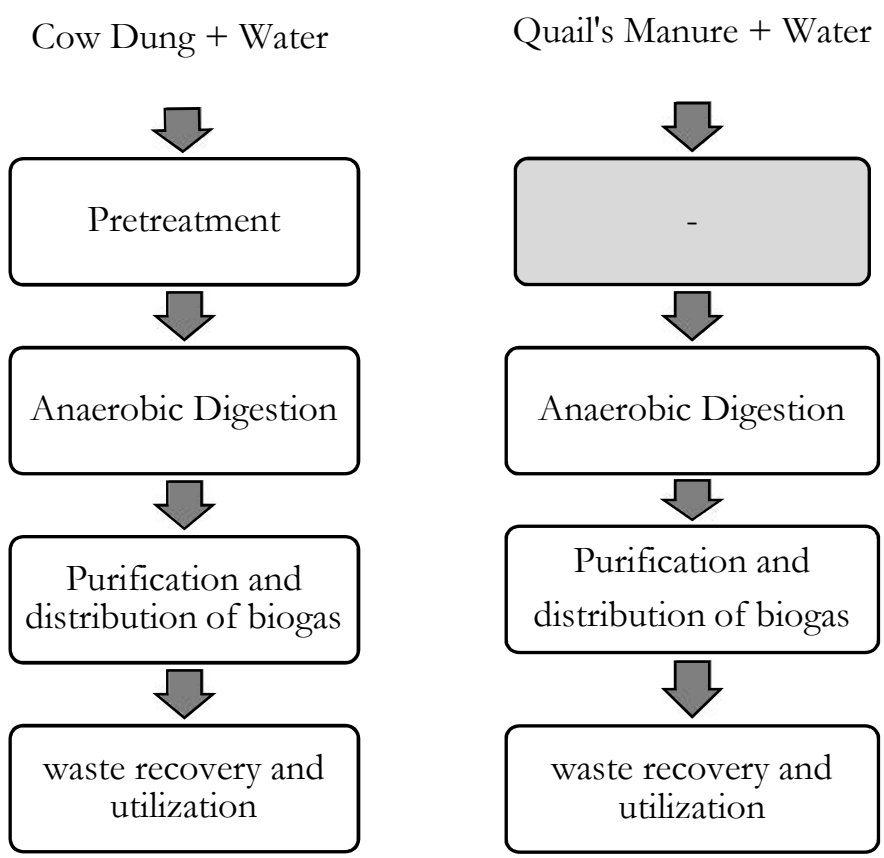

Tofu Waste Water

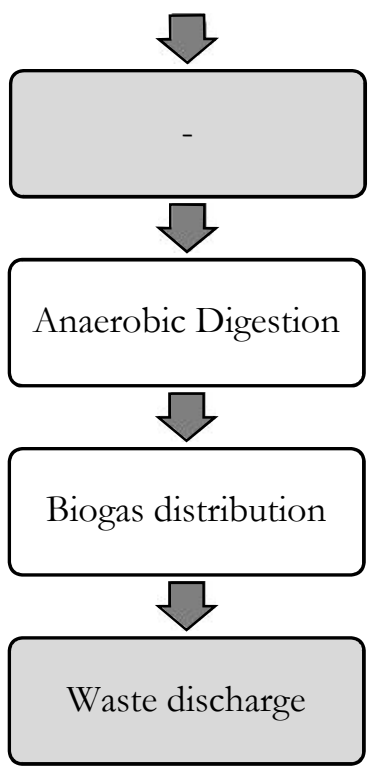

Fig. 1. Comparison of biogas production chart for different feedstock.

Figure 1 clearly shows that cow dung as anaerobic digester feedstock needed to be pretreated. On site, the cow dung is usually accidently mixed with dried leaves, straws, and branches based on our observation and interview. The presence of dried compound in the cow dung could cause blocking on the pipe. The dried material is lighter than the slurry which stays at the top. When gas start to generate, some of the dried material gets taken away by the gas and enter the distribution pipe resulting lower biogas production rate. Quail manure and waste water of tofu production are easy to collect due to availability of the manure collector and well filtrated drains thus do not need extra pretreatment process

Biogas production process from tofu industry could be adapted as an alternative method to treat waste water. The effluent or overflow of the biodigester is relatively safe to be discharged to the environment according to our interview with Surakarta's environmental agency officer. While the overflow of the biodigester in the tofu industry is directly discarded to the river, the effluent of digester installed in Izzah farm can be divided into two group of overflow. The first overflow is often collected and further processed into bio-fertilizer, while the second overflow is channeled to a catfish pond which believed could be increase the growth of the catfishes. The photograph of liquid bio fertilizer and the catfish pond could be seen in Figure 2. 


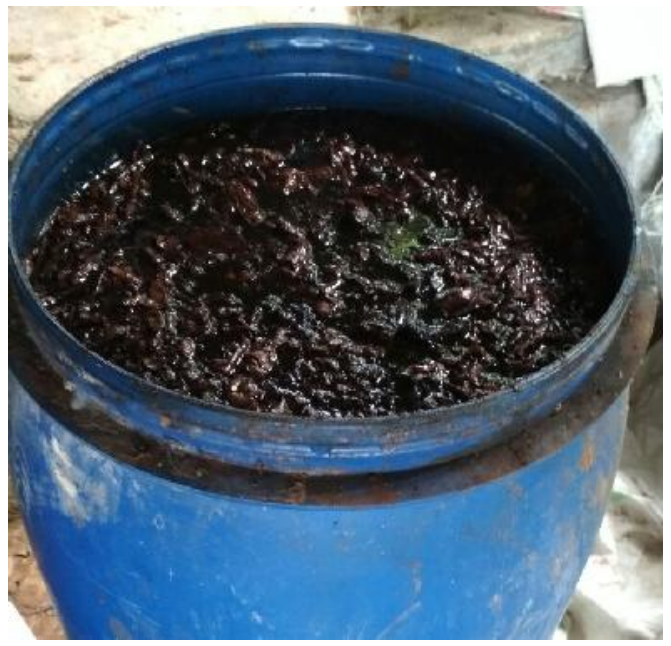

(a)

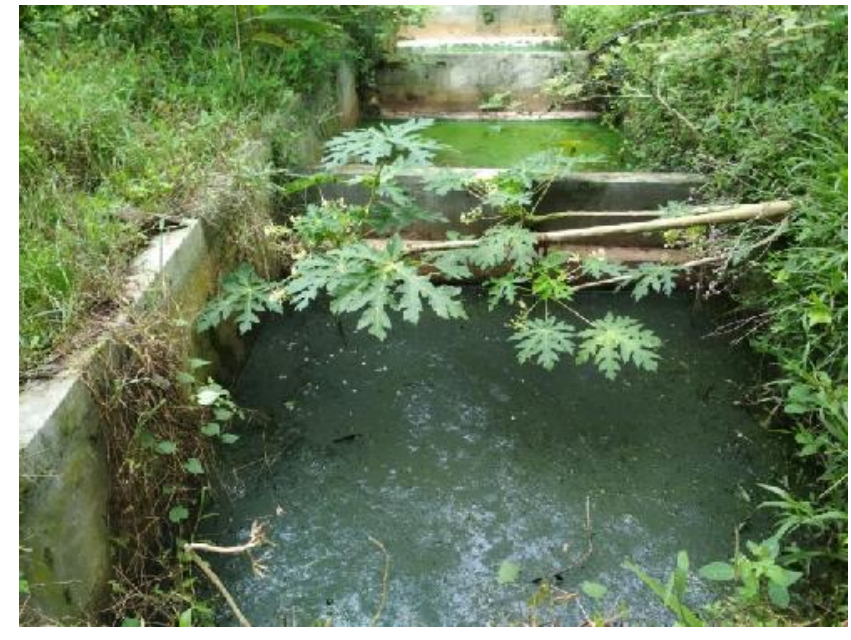

(b)

Fig. 2. Biofertilizer from biogas first overflow (a) and catfish pond flowed by second overflow (b).

The specific parameter of each process shown in Figure 1 is listed in Table 2. Each biodigester need retention time to produce biogas. For each feedstock, the retention time is varied. The retention time could also caused by the concentration of the digester input. To produce biogas continously, the input also need to be fed in to the digester periodically and consistantly.

Tabel 2. Field study and observation results.

\begin{tabular}{|c|c|c|c|}
\hline Parameter & $\begin{array}{c}\text { Biogas from cow } \\
\text { dung }\end{array}$ & $\begin{array}{c}\text { Biogas from quail } \\
\text { manure }\end{array}$ & $\begin{array}{l}\text { Biogas from tahu } \\
\text { waste water }\end{array}$ \\
\hline Capacity & $50-70 \mathrm{~m}^{3}$ & $50-70 \mathrm{~m}^{3}$ & $170 \mathrm{~m}^{3}$ \\
\hline Feedstock source & $\begin{array}{c}10-15 \text { Cows (metal) } \\
\text { per digester }\end{array}$ & $\begin{array}{c}3000 \text { quails per } \\
\text { digester }\end{array}$ & $\begin{array}{l}700 \mathrm{~kg} \text { soybean } \\
\text { processed per day }\end{array}$ \\
\hline Input process to Digester & Manually, once a day & $\begin{array}{c}\text { Manually, once } \\
\text { every } 4 \text { days }\end{array}$ & Automatically \\
\hline Retention time & 3 days & 14 days & 40 days \\
\hline Pretreatment & $\begin{array}{c}\text { Dried leaves } \\
\text { separation }\end{array}$ & None & None \\
\hline Post-treatment & $\mathrm{CaCO}_{3}$ adsorber & $\mathrm{CaCO}_{3}$ adsorber & None \\
\hline Biogas uilization & Domestic/household & $\begin{array}{c}\text { Domestic/House- } \\
\text { hold }\end{array}$ & $\begin{array}{l}\text { Domestic and } \\
\text { Industry }\end{array}$ \\
\hline
\end{tabular}

\subsection{Utilization of Biogas Product}

In these three cases, biogas is utilized slightly different from one to another. The biogas obtained from cow dung and quail manure is used for cooking and lighting via modified stove and petromax lamp. Each biodigester installed in could supply daily fuel needs for domestic cooking for up to ten housings. While the biodigester installed on tofu industry, the biogas produced is utilized as fuel for cooking and also utilized as fuel for boiler which greatly reduce the wood/biomass as the conventional fuel for the boiler. As the summary, the produced biogas greatly reduce the daily fuel need for cooking $100 \%$ hence each household could save more money and energy. 


\subsection{The Obstacles in Developing Biogas}

Based on Indonesian Ministry of Energy and Mineral Resources data, the development of biogas in Indonesia is still considered slow. Since the first recorded socialization regarding biogas in 1970 till 2014 there are only 9.000 unit biogas established by private companies and goverment which means in only less than $0.1 \%$ household that apply such technology. Thus biogas has not give any impact qualitatively and quantitatively upon national's energy need in domestic sector yet [12]. This fact proves that penetration of biogas technology in industries and households is facing obstacles. Based on our observation and interview records, main obstacles that hindered the application of biogas technology in Indonesia is listed as folow:

1. Feedstock limitation

Based on our observation, only farm participans and small food business owner has the opportunity to develop biogas installation due to the availability of feedstock on daily basis. Mean while other regular citizen which often stay in sub-urban area or even urban area has difficult way to obtain steady biogas input or feedstock almost all of organic matter could be converted into biogas.

2. Limited area

The biodigester adapted in Indonesia is mostly dome-shaped which need some of household area, reducing the feasibility if it is going to be adapted in households. The area become less productive making it less attractive among citizens.

3. Biogas installation maintenance

The manual of biogas maintenance and operation has been released by the goverment, but many people still find it hard to be understand. Violation of each operational procedur, the productivity of biodigester system is severed. Based on our observation, the procedure that often being violated is listed as follows

a. Feedstock input procedur : The feedstock, like in cow dung biogas case, is needed to be free from dried leaves, grasses and branches. Some of the user often forgot to perform a separation process which later reduce the biogas production and need to be cleaned often due to the plugged pipe.

b. Household scheduling for feedstock input :The scheduling need to be obeyed by the user due to daily feedstock dosing of the biodigester. When the scheduling is forgotten, it means there is no feedstock to convert hence the generation of biogas is stopped.

c. Piping blowdown addition and checking : The generated biogas often carry small amount of water which could accumulate in the piping causing mechanical damages. The blowdown need to be installed and opened periodically to discard the acumulate condensate.

d. Underground PVC installation : The risk of leakage could be reduced by this method.

e. Adsorber installation : The addition of adsorber could hinder the corrosion caused by $\mathrm{H}_{2} \mathrm{~S}$ and $\mathrm{CO}_{2}$ gas which have corrosive properties.

f. High investment needed: Based on our interviews, the cost of biogas installation is no smaller than Rp. $15.000 .000,00$ or about US $\$ 10.000$ (1 USD $=15.000$ IDR) while the payback period or break even point could be reached after 8 years of operation excluding the maintenance cost.

Based on the obstacles listed above, the main problems occurs realy heavily on the users or the people who use biodigester. This social problems needed to be overcome by strict regulations and monitoring. With repeating violation againts the procedures, it is calculated that the life time of biogas installation only lasted for two years while with good maintenance and operation, biogas installation could lasted for 25 years. It means biodigester is very promising technology for rural energy supplies.

\section{Clonclusions}

Cow dung and Quail manure could be applied as biogas feedstock while the side product could be used as Nitrogen - rich bio fertilizer thus boosting the economic value of cattle manure. The biogas could be used directly to substitute LPG and other gaseous fuels for cooking or as boiler fuel. In spite of that, the development of biogas is considered slow due to social aspect problems. Therefore, we propose a recommendations listed as follow:

a. each installation need to be monitored and strictly supervised to optimize the biogas production,

b. campaign on biogas installation maintenance need to be performed periodically, and

c. the research about biogas should be based on real - world problems and aimed to optimize our current biogas installation. 


\section{Acknowledgement}

The authors is grateful to Universitas Sebelas Maret for the financial support through funding scheme Penelitian Unggulan Terapan UNS (PUT-UNS) PNPB 2018 contract number 543/UN27.21/PP/2018 and Mr. Sulistyo, S.T. and the officer of Surakarta's Environmental Agencies (KLH) who are willing to be our interviewee.

\section{References}

[1] S. D. Minteer, Handbook of Biofuels Production. 2011.

[2] J. Lizasoain et al., "Corn stover for biogas production: effect of steam explosion pretreatment on the gas yields and on the biodegradation kinetics of the primary structural compounds," Bioresour. Technol., 2017.

[3] O. I. Nwaukwu IA, "Generation of Biogas from Cow Dung," J. Bioremediation Biodegrad., vol. 5, no. 2, pp. 2-4, 2014.

[4] Y. Li, R. Zhang, C. Chen, G. Liu, Y. He, and X. Liu, "Bioresource Technology Biogas production from co-digestion of corn stover and chicken manure under anaerobic wet, hemi-solid, and solid state conditions," Bioresour. Technol., vol. 149, pp. 406-412, 2013.

[5] R. Ahmad Dar, E. Ahmad Dar, A. Kaur, and U. Gupta Phutela, "Sweet sorghum-a promising alternative feedstock for biofuel production,” Renew. Sustain. Energy Rev., no. June 2016, pp. 0-1, 2017

[6] F. Wang et al., "Bioresource Technology Enhancing biogas production of corn stover by fast pyrolysis pretreatment," Bioresour. Technol., vol. 218, pp. 731-736, 2016.

[7] F. Wang et al., "Enhancing biogas production of corn stover by fast pyrolysis pretreatment," Bioresour. Technol., 2016.

[8] N. Scarlat, J. Dallemand, and F. Fahl, "Biogas : Developments and perspectives in Europe," Renew. Energy, vol. 129, pp. 457-472, 2018.

[9] S. Achinas, V. Achinas, G. Jan, and W. Euverink, "A Technological Overview of Biogas Production from Biowaste," Engineering, vol. 3, no. 3, pp. 299-307, 2017.

[10] H. Wang, J. Xu, L. Sheng, and X. Liu, "Effect of addition of biogas slurry for anaerobic fermentation of deer manure on biogas production," Energy, 2018.

[11] Ž. Michal, H. Bendová, K. Friess, J. E. Bara, and P. Izák, "Single-step purification of raw biogas to biomethane quality by hollow fiber membranes without any pretreatment - an innovation in biogas upgrading," Sep. Purif. Technol., 2018.

[12] R. Putra, A.R.S., Z. Liu, and M. Lund, "The impact of biogas technology adoption for farm households - Empirical evidence from mixed crop and livestock farming systems in Indonesia," Renew. Sustain. Energy Rev., vol. 74, no. May, pp. 1371-1378, 2017. 